\title{
Meet the Others: Comprehending Crowdsourcing Graphic Design Practice in Indonesia
}

\author{
Taufik Murtono \\ Indonesia Institute of the Arts Surakarta, Indonesia \\ Santosa Soewarlan \\ Indonesia Institute of the Arts Surakarta, Indonesia \\ Didit W. Soewardikoen \\ Telkom University Bandung, Indonesia \\ Guntur \\ Indonesia Institute of the Arts Surakarta, Indonesia
}

\begin{abstract}
Visual communication design (VCD) research has so far been dominated by the study of artifacts rather than the design process. The study of the VCD process from a design perspective has not been taken seriously. The stagnation of research for design is influenced by the establishment of the modern design world along with its standard methods. Meanwhile, the world has changed, supported by advances in internet technology that is forming new systems and arrangements. Crowdsourcing is a phenomenon when the internet as an information medium develops into social media and crowd-based capital. The industrial revolution 4.0 gave rise to new companies with information technology platforms. One popular area of crowdsourcing is graphic design. The graphic design crowdsourcing page brings together a community of designers and clients from all over the world. Indonesia providesone of the biggest graphic design crowdsourcing actors in the world. This research tries to go beyond standard, by preferring a study of designer community. Community members are seen as subjects who have knowledge of work experience in crowdsourcing graphic design systems. The large number of crowdsourcing designers in Indonesia who have survived in the community since 2008 certainly wasnot instantly formed. The phenomenon of crowdsourcing graphic design community in Indonesia in building theirexistence can be important knowledge when we are open-mindedly examiningthe presence of others.
\end{abstract}

Keywords: Crowdsourcing, concept, graphic design, community, Indonesia.

DOI: $10.7176 / \mathrm{ADS} / 76-03$

Publication date:September $30^{\text {th }} 2019$

\section{Introduction}

The crowdsourcing phenomenon of graphic design is a continuation of the existence of the internet. The internet, which was originally an information media, has developed into social media and crowd-based capital. Peoples who gather in online communities are resources that can be utilized for industrial purposes. Crowdsourcing is a system of community involvement to obtain input, information, and so on for an activity, especially through the internet.Crowdsourcing can be in the form of skills, knowledge, or funds with the aim of mutual benefit. Internet technology has become an important tool in establishing crowdsourcing systems. The fourth wave of the industrial revolution through the continued role of the internet gave rise to new companies with information technology platforms. The internet allows people to gather on social media and be a resource of this system. Daren C. Brabham indicates the requirement ofinternet as an online media and the synergy of several elements, such as the organizations receiving the results of crowdsourcing, crowdsourcing community, online systems that connect recipients and actors, as well as the mutually beneficial situation of both parties (Brabham 2013, 3). One popular area of crowdsourcing is graphic design. The graphic design crowdsourcing page brings together a community of designers and clients from all over the world. The most popular systems are paid competitions (graphic design contest) and buying and selling graphic design via the internet (graphic design marketplace).

Indonesia is one of the countries with the greatest graphic design crowdsourcing potential in the world. Tech in Asia said that Indonesia and the Philippines are the countries with the largest number of graphic design crowdsourcing actors in the world (Wee 2013). This statement is supported by data from Jason Aiken, Community Director of 99designs.com which states that there are 225,000 graphic designers from 192 countries registered at 99designs.com and 17,000 of them are from Indonesia (Bisnis.com 2013). The large number of crowdsourcing graphic designers in Indonesia undoubtedlyhas certain ways in shaping their existence. The latest data on the Zilliondesign page shows the predominance of crowdsourcing from Indonesia.

One factor that indicates the existence of a community is the issue of whether activities in the community contribute to sustainable benefits. As an illustration, one of the prominent crowdsourcing graphic designer 
communities is located in Kaliabu Village, Salaman District, Magelang Regency, Central Java. In a glance, Kaliabu Village is no different from other villages in Indonesia. The occupationsof the population are diverse, such as factory workers, traders, farmers, and ranchers, some of themare unemployed. Most of them are junior and senior high school graduates. However, there has been an interesting activity in Kaliabu Village since 2012. After working, some of the residents started their activities as graphic designers. They work by entering graphic design contests on crowdsourcing sites. Crowdsourcing pages provide hundreds of graphic design contests every day with prizes ranging from hundreds to thousands of dollars. Contest owners are clients from various countries who need graphic design services.

The number of Kaliabu villagers who work as graphic designers currently reaches 250 people. They establishes a community called Rewo-rewo. Over a span of two years (2012-2014) the community was able to generate six billion Rupiahs (Muhzawawi and Aprianto 2014). The quite large figure of income illustrates that villagers who have not educated in art or design institutionare able to be empowered in a graphic design crowdsourcing competition.

The phenomenon that occurred in Kaliabu Village was actually not the first in Indonesia. Graphic designers in Surakarta and other cities such as Surabaya, Yogyakarta, Tegal, Semarang, Jakarta, and Bandung have stormed crowdsourcing contests since 2007. Many of them are designers without formal education. In 2012 graphic designers from several cities held an informal meeting in SUrakarta, to get to knoweach other in person. But in this issue, the way Kaliabu Villagers joining the competitions was the most prominent phenomenon, because it involved so many residents in one village. It is strongly suspected that the number of graphic design crowdsourcing pages will continue to grow in the future. The large number of graphic design crowdsourcing actors in Indonesia indicates that these designers have marked their own placein the graphic design industry.

On the other hand, the phenomenon of crowdsourcing graphic design was in fact opposed by industry, professionals, and design associations. Crowdsourcing is considered a system that damages the graphic design industry through speculative work. It is considered as having low standards because online systems open up the opportunity for anyone, including they who have not had proper education, to participate in becoming a designer. The issue of design quality and ethics is the main focus of professionals. The American Institute of Graphic Arts (AIGA) page of the design profession association in America states that that they reject crowdsourcing graphic design. This system (is referred to as spec work or speculative work) is risky for both clients and designers ("AIGA position on spec work." 2009). For the same reason, the spec.com page even lists many associations such as AGDA (The Australian Graphic Design Association), CSD (Chartered Society of Designers, UK), DINZ (Designers Institute of New Zealand), GAG (Graphic Artists Guild, US), GDC (The Society of Graphic Designers of Canada), Icograda (International Council of Graphic Design Associations), ICSID (International Council of Societies of Industrial Design), IDI (Institute of Designers in Ireland), RGD (Association of Registered Graphic Designers), and SEGD (Society for Environmental Graphic Design) as part of the rejection for the same reason ("NO!SPEC Design Organitations" 2011).

Some prominent graphic design practitioners also expressrejection through their personal pages. Like David Airey who openly refused a job offer without legal agreement. It wasconsidered unprofitable and speculative (Airey 2010). Pamela Pfiffner agreed with Airey by stating that crowdsourcing is similar to speculative work because it cuts the paid professional work system through open bidding on the crowdsourcing page (Pfiffner 2009).

Graphic design method that is centered on designers'creative power can be said to have created arrogance through the establishment of concepts that are supported by professionals, industry, and education. The establishment can create a status quo that is closed to changes, especially changes that come from outside. For this reason, this research tries to go beyond the professional views that hold fast to design standards, preferring to study the experiences of the designer community. Community members who are mostly non-formal people are seen as subjects who have knowledge of experience in overcoming work in crowdsourcing graphic design systems. The large number of crowdsourcing designers in Indonesia who have survived in the community since 2008 certainly did not form.

The phenomenon of crowdsourcing graphic design community in Indonesia in establishing theirexistence can be an adequate contribution of knowledge when examined with an open view of seeing the success of others. This research will focus on the issue of the concept of Indonesian self-taught graphic designerswho stormed the graphic design crowdsourcing page amid criticism from professionals. The existence of these designers shows their concept is accepted by users.

The concept of design is a collection of embodiments of the designer's mind that includes the whole ideas, qualities, situations, and feelings that are required (Provost and Langley 1998, 1). Thus, the graphic design concept of crowdsourcing community in Indonesia relates to knowledge that is built with a variety of human characters in it. This is considered important because thefindings can become contributionfrom "others" for the academic world and the graphic design industry. The knowledge gained in the research of the graphic design crowdsourcing community will have value for researchers and academics who have so far adopted more 
standardized principles, methods, and modern design ethics. Community experience will contribute in thediversity ofdesign practice.

\section{Crowdsourcing literature review}

The visual communication design (VCD) topic has been examined from various disciplines, such as culture, social, history, technology, and law. VCD has long attracted cultural researchers. One of the writings that became a role model for subsequent researchers was "Mythologies" by Roland Barthes. The core issue of the VCDs highlighted is that everything that is communicated by the producer is not proper, prevalent,or natural because everything is an ideological-laden engineering (Barthes 1972, 36). VCD and social change supported by technological development are examined by Stephen T.F. Poon presents the nodes of the socio-historical development of the 19th to 20th century VCDs (Poon 2015, 5-9). VCD historical study is a documentation of visual expression that is influenced by the visual arts movement with all its dynamics (Triggs 2009, 325-40). The study of technological developments has proven to affect designer'screativity. Technology makes it easy for designers to transformideas into solutions (Bonnardel and Zenasni 2010, 180-91). While the correlation betweenVCD andthe law and ethics realm is a fairly complex study which includes a discussion about connectionamongdesigners, users, and industry with all inherent legal issues.

Studies that focus on graphic design crowdsourcing phenomenoncan be traced since Jeff Howe revealed the phenomenon of crowdsourcing in its early development. Howe discusses photography pages such as istockphoto.com, shutterstock.com, dreamstime.com, and gettyimages.com. In addition to photography, crowdsourcing video broadcasts, including Web Junk 20, Outrageous \& Contagious Viral Videos, Cybersmack and Carson Daly's Cyberhood, and crowdsourcing in more complex work such as product research and development, are on innocentive.com pages.(Howe 2006). Howe opened the eyes of the world to the power of crowd, facilitated by the market through the internet, which has become a competitor of the established professional and industrial world. In another article Howe stated the rise of amateurs he called crowdsourcing engine fuel (Howe 2009, 23). Crowdsourcing work systems with characters that are easier, faster, cheaper, even smarter, are weapons that professionals and industry should be on the lookout for. An overview of crowdsourcing was also written by Daren C. Brabham with a discussion of concepts and case studies of several crowdsourcing pages from the aspect of business management. Some crowdsourcing pages are broken down by function, such as information gathering functions (peertopatent.org, seeclickfix.com), creativity and design (threadless.com, crashthesuperbowl.com, nextstopdesign.com), problem solving science and technology (innocentive.com), and data analysis (mturk.com)(Brabham 2013, 3).

Referring to the research of Arie Yulfa crowdsourcing has an important role in community development. Based on the assumption that the involvement of many parties in a process is very important, this article describes the role of internet technology as a medium to support regional planning in a crowdsourcing system (Yulfa 2012, 13-23). The existence of some crowdsourcing graphic designers in Indonesia is indicatedin Ratna Cahaya Rina's research aboutKaliabu Village in Magelang Regency, which is famous for having hundreds of crowdsourcing graphic designers. Rina highlighted the designers'financialsustainability in the village. They rely on crowdsourcing to fundtheir actual job, such as a printing business, internet cafes, and so on. Financialproblems will be one of the things that influence the motivation that led to the existence of the designer (Rina 2016, 1-5).

The crowdsourcing phenomenon has spread rapidly in a relatively short period of time. Crowdsourcing system is also seen as a potential that needs to be further investigated, especially on the strong aspects of designer motivation and the utilization of their potential for mutual progress (Hammon and Hippner 2012, 16568). This phenomenon is currentlyconsidered important, because anyone connected to the internet can participate in a crowdsourcing system. Crowdsourcing offers many problem solving options that can be chosen, including financial, education, product development, security, hobbies, and entertainment. This system opens up opportunities for countries to participate in solving national problems, such as hardware and software development problems. In addition, Indonesia is a country with a large crowd potential that can be utilized to support crowdsourcing systems (Andriansyah, Oswari, and Prijanto 2007, 1-6).

Aside from identifying systems and business opportunities, research on designers in crowdsourcing systems mostly consists of spatial research and attempts to prove motivation theory. Proof that has been done, among others, is the theory of personal motivation in crowdsourcing (Zhao and Zhu 2012, 1-13). The motivation for getting prize money is a strong impetus for the designer (Ståhlbröst et al. 2015, 1-17). Proof is also carried out through experimental research which concludes the correlation between the size of the prize, the ease and duration of the contest influences the designer's interest and the quality of the design produced. (Shao et al. 2012, 73-82).

Research that is more focused on graphic design crowdsourcing was conducted by Adrienne Massanari who succeeded in identifying changes in the graphic design profession along with improvementin internet technology. Massanari concluded that crowdsourcing is an interesting phenomenon because it implies things such as forming 
a community that is able to support the interests of users, become a means of mutual learning between the community and users, and a fairer payment system is still needed by involving certaindesigners for specificjobs (Massanari 2012, 1-14). Despite having the same research focus, Massanari did not explain further about the experience of the learning and working community through this system. The weakness of this research is that it is done through system observation alone, without being directly involved with the daily lives of the community so that it does not gain knowledge from the perspective of the perpetrators.

Early research into graphic design crowdsourcing phenomenon in Indonesia illustrates the existence of designers formed through motivationdevelopment. Despite opposition from professionals and often get caught up in violations of graphic designethics, it gives a positive impetus to the perpetrators. Their motivation has developed, starting with motivation 1) money seeking 2) expanding the network 3) increasing the skill4) getting a direct job and 5) fundraising for more tangible businesses (Murtono and Soewardikoen 2017, 187-93).

\begin{tabular}{ll}
\hline Author, Year & Title \\
\hline Howe 2006 & The Rise of Crowdsourcing \\
\hline Howe 2009 & $\begin{array}{l}\text { Crowdsourcing: How the Power of } \\
\text { the Crowd is Driving the Future of } \\
\text { Business }\end{array}$
\end{tabular}

Results and Discussion

Initial research that uncovered the crowdsourcing phenomenon in the early development with several pages discussion of stock trading, graphics, and other ideas via the internet.

The power of the crowd through the internet is becoming a professional and established industry competitor through an easier, faster, cheaper, and smarter crowdsourcing system.

\begin{tabular}{lll}
\hline $\begin{array}{l}\text { Brabham } \\
2013\end{array}$ & Crowdsourcing & $\begin{array}{l}\text { Identify the crowdsourcing page from the business } \\
\text { management aspect. Some crowdsourcing pages are } \\
\text { broken down by function. }\end{array}$ \\
\hline Yulfa 2012 & $\begin{array}{l}\text { Crowdsourcing sebagai Upaya } \\
\text { Melibatkan Peran Masyarakat } \\
\text { dalam Proses Perencanaan Wilayah }\end{array}$ & $\begin{array}{l}\text { The role of internet technology as a medium to support } \\
\text { regional planning in a crowdsourcing system }\end{array}$ \\
\hline
\end{tabular}

Rina 2016 Kaliabu dan Salaman, Ketika The existence of crowdsourcing graphic designers in Internet Telah Menjamahmu: Cerita Kaliabu Village, with the finding of financialviability of tentang Desainer Kampung di the designers in the village who relied on crowdsourcing Indonesia to fundtheir other jobs.

Hammon dan Crowdsourcing Crowdsourcing has spread rapidly and is seen as a Hippner 2012 potential that needs to be further investigated, especially in the strong aspects of the actors'motivations and the utilization of their potential for mutual progress.

\begin{tabular}{|c|c|c|}
\hline $\begin{array}{l}\text { Andriansyah } \\
\text { et.al } 2007\end{array}$ & $\begin{array}{l}\text { Crowdsourcing: Konsep Sumber } \\
\text { Daya Kerumunan dalam Abad } \\
\text { Partisipasi Komunitas Internet }\end{array}$ & $\begin{array}{l}\text { Indonesia is a country with a potential crowd that can be } \\
\text { utilized to support the solving of national problems, such } \\
\text { as hardware and software development. }\end{array}$ \\
\hline $\begin{array}{l}\text { Zhao dan } \\
\text { Zhu, } 2014\end{array}$ & $\begin{array}{l}\text { Effects of Extrinsic and Intrinsic } \\
\text { Motivation on Participation in } \\
\text { Crowdsourcing Contest. A } \\
\text { Perspective of Self-determination } \\
\text { Theory }\end{array}$ & Proof of personal motivation theory on crowdsourcing. \\
\hline $\begin{array}{l}\text { Ståhlbröst } \\
\text { et.al. } 2015\end{array}$ & $\begin{array}{l}\text { Understanding Modes of } \\
\text { Crowdsourcing and Related Crowd } \\
\text { Motivators }\end{array}$ & $\begin{array}{l}\text { The motivation for getting prize money is a strong } \\
\text { impetus for the designer. }\end{array}$ \\
\hline $\begin{array}{ll}\text { Shao et.al. } \\
2011\end{array}$ & $\begin{array}{l}\text { Factors Affecting Participation of } \\
\text { Solvers in Crowdsourcing: an } \\
\text { Empirical Study from China }\end{array}$ & $\begin{array}{l}\text { The correlation between prize size, convenience, and } \\
\text { duration of the contest affects the designer's interest and } \\
\text { the quality of the design produced }\end{array}$ \\
\hline $\begin{array}{l}\text { Massanari } \\
2012\end{array}$ & $\begin{array}{l}\text { DIY Design: How Crowdsourcing } \\
\text { Sites are Challenging Traditional } \\
\text { Graphic Design Practice }\end{array}$ & $\begin{array}{l}\text { Crowdsourcing is able to form a community from the } \\
\text { bottom up, becoming a means of mutual learning } \\
\text { between the community and users, but a fairer payment } \\
\text { system is still needed. }\end{array}$ \\
\hline $\begin{array}{l}\text { Murtono \& } \\
\text { Soewardikoen } \\
2017\end{array}$ & $\begin{array}{l}\text { The Existence of Crowdsourcing } \\
\text { Graphic } \\
\text { Designers in Indonesia }\end{array}$ & $\begin{array}{l}\text { Motivation that forms existence. The development of } \\
\text { crowdsourcing designer motivation in Indonesia 1) } \\
\text { money seeking 2) expanding the network 3) increasing } \\
\text { the skill4) getting a direct job and 5) fundraising for } \\
\text { more tangible businesses. }\end{array}$ \\
\hline
\end{tabular}

Table 1. Literature Review. 
In addition to Massanari's research, some of the research results that have been mentioned only discuss crowdsourcing in general, with the research findings of quantitative data regarding the number of crowdsourcing actors, motivation, and the possibility of developing this system. Thus this research has the opportunity to gain knowledge about crowdsourcing system of graphic design in Indonesia, especially in an effort to uncover the experiences of designers and users, in order to obtain the concept of community graphic design that can enrich the repertoire of design methods. In addition, there is no research that can answer the factors that influence the graphic designcrowdsourcing community of Indonesia, whose existence is so dominant among other countries.

The theoretical assumptions of this research are composedstarting from graphic design concepts to social concepts, and philosophical perspectives needed to uncover the knowledge. This assumption is in line with the opinion that art research covers physical art issues as well as space and time. Physical art is an intraesthetic factor related to forms, principles, techniques, and ideas. Whereas space and time are extraesthetic factors which include socio-cultural aspects (Rohidi 2011, 75). To achieve the goal of seeing the graphic design community crowdsourcing practice, Emmanuel Levinas's thoughts on ethics stem from an awareness that opens the ego to be questioned by others. The social aspect of crowdsourcing is approached through Clayton M. Christensen's thoughts on disruption and public space initiated by Habermas. While concepts related to graphic design such as creativity, design principles, computer graphics technology, designer experience, designer and user relations, and design ethics are used and are the concepts discussed in research.

\section{Crowdsourcing designer creativity}

Graphic design activities, however, are shaped by creative work, although the notions of creativity are quite diverse. However, in general creativity is the ability to produce new ideas or items that are usually surprising and useful (Boden 2004, 1). Creative abilities are related to experience and are not formed suddenly. The seemingly sudden results of creativity are actually formed through the gathering of time-consuming experiences (Young 2003, 17-21). Creativity if illustrated as a coral island that seems to appear on the surface of the sea suddenly, even though the clusters of coral are formed by coral animals that work in the depths of the sea for a long time.

If ideas are the end result of long process of gathering experience, then the process can certainly be traced and mapped out patterns. The pattern in question is a series of mindwork in producing creativity. To initiate an understanding of creative mindset, it is necessary to allude to Vilfredo Pareto's (1848-1923) thought, which divides human types into two namely rentier and speculator. Rentier is the type of person who likes establishment, on the contrary the speculator is a person who likes challenges and has a creative spirit. People who are comfortable with the establishment are usually defeated by creative people through new ways of competition (Femia 2006, 107-8). Furthermore, to understand creative practice, it is necessary to know two principles of idea creation, namely, first the idea is actually just a new amalgamation of old elements and the ability to connect these old elements into new ideas is needed. Ideas are usually formed through several stages, starting with the collection of knowledge, digestion of knowledge, subconscious thinking, the emergence of ideas, to perfection (Young 2003, 33-39).

Through creativity theory, crowdsourcing graphic designers are assumed to have the ability to generate ideas that are useful for users. The idea owner is usually a person who likes challenges. The resulting ideas do not appear in sudden.Instead, it appearsthrough a process. A search of the idea creating process can be carried out by knowing the design projects and past experiences that lay behind the designer's personalities. It is important to know how the designer combines past experience with knowledge related to design projects.

\section{Design principles}

This life is filled with visual communication and makes humans as beings who are very concerned about graphic stimuli. Therefore half of the work of the human brain is used to process objects that are seen (Weinschenk 2012, 14). This statement is in line with the findings of John Medina showing that images are easier to understand and remember. People can only remember $10 \%$ of the information they hear, but adding images increases the percentage of memories to $65 \%$ (Medina 2008, 246). By weighing the important role of visualelements in communication, the principles of graphic design need to be studied.

The practice of graphic design can be seen from the most basic design principles, namely contrast, repetition, alignment, and closeness. These four principles are the basis for every design activity (William 2004, 13) and so far it is believed to be a guideline to measure the success of a design (Sammons and Daniel 2017, 1314). The design principle can be applied to each element, such as tone (dark-light difference), color, size, shape, and texture.

Whenvisual communication plays an important role in life, then the basic principles need to be learned to achieve the success of the message. These basic principles include contrast to highlight uniqueness, repetition to achieve attachment, alignment to achieve rhythm in accordance with audience habits, and grouping based on the closeness of the nature of the design elements to achieve unity and ease of understanding of information.

The fact that crowdsourcing graphic designer community is considered as a groupof people who do not 
master the design principles academically opens up the possibility of different practices. The principle of contrast, repetition, alignment, and closeness can also be explored further, not limited to the technical application of graphic design but can also be within the scope of the manner and styleof the design. In order to understand the ways and stylesof design in relation to the principles of contrast, repetition, alignment, and closeness it is necessary to review how crowdsourcing graphic designers in Indonesia are shaped by their socio-cultural environment.

\section{Past experience in design practice}

The quality of design practice depends on the maturity of the designer so that it takes quite a long time through the process of learning and working to shape it. To understand design, it is important to realize that the practice includes the role of teams, communication, and sharing experiences. For this reason, exploration of design practice that focuses on past experience is arranged in an unconscious scheme. This scheme is usually used by the designer to recognize the design situation and determine the initial steps. Bryan Lawson concludes that design expertise cannot be understood simply by learning actions. Instead, wealso need to trace the designer's past experience that influences design decisions (Lawson 2004, 106-7).

The learning and work process in crowdsourcing graphic designer community happens informally through communicationsamongcommunity members and discussions with potential users. The design process in the community indicates a pattern of learning from past experiences. When new personsenter the crowdsourcing system, the situationcertainly involves certain motivations and ways of learning. Description about work experience produces a design that is accepted by the user. The interaction between designer andthe user becomes an important part because it becomes a determinant of the success of a design. Past experiences and learning processes in the community can be aninfluencing factor forthe designer.

The phenomenon that occurs in the designer community is seen as a experience in process of learning, working, and actualizing the ability to overcome problems in a system. Bryan Lawson's thoughts about design issues such as ideas, actions, and design principles, references, to characteristics and design variants occupy a central position in the theoretical framework. Furthermore Lawson stated the need to reveal the designersknowledge. They usually have a special way to gain knowledge and utilize that knowledge in the design process(Lawson 2004, 1-5). The designer community with diverse backgrounds and experiences in this research needs to be mapped in order to understand the correlation of experiences of one with the others.

The non-formal designer community in Lawson's view is persons who have empirical experience and an important source of knowledge. This was proven when a group of first-year students from Sheffield University visited the Eskimo tribal settlement at the cornerof Antarctica. The students were asked to experimentinginbuilding houses usinglocal materials. The result was that all of their experiments failed to deal with the extreme weather there. Eventually they ignored the design structure that was in mind and built the igloo (dome-shaped traditional house of the Eskimos). After that, the students examined the igloo structure they were working on (Lawson 2004, 17-20). For non-formal designers, design activities seem to flow away without involving thoughts about the principles of design.

Basically, among industrial society, design is a professional activity. Even today there is a clear division in the design field. Each professional is specifically educated and works according to the specifications. Higher education has long divided the fields of design studies specifically such as design, graphics, textiles and clothing, interiors, and so forth. Designers of college graduates must be educated to produce specific types of goods. But in practice this is not always the case. Design is not always a professional activity as in general.

which ever forms ofdesign produced by the crowdsourcing system, and who ever does it, certainly it was producedthrough a process. Design graphics isa systematic process that involves the creative mind. This process starts from the client briefing to the solution through the design. The resulting solutions can vary in their levels of creativity, practicality, and costs according to the demands of the brief. The design process as an act of creative thinking includes a series of stages, including identification, research, formulation of ideas, prototyping, selection, application, and evaluation (Ambrose and Harris 2011, 6-13).

Asidefrom the easy way in having computer and graphic design applications in Indonesia, crowdsourcing participator especially those from non-formal groups have a learning process to be able to participate in this system. The learning model that occurs is like a discovery learning process. Jerome S. Bruner describes learning discovery in a constructive perspective as a learning model for forming understanding through personal experiences and interactions with external factors. Learning discovery emphasizes understanding concepts, meanings, and relationships, through an intuitive process that leads to a conclusion (Bruner 1966a, 87).

Bruner divides cognitive development into three stages that are determined by the environment, namely the enactive, iconic, and symbolic stages. Enactive stage is the activity of understanding the environment with motor knowledge such as touch and hold. The iconic stage is a way of understanding the environment through images (appearance) and comparison (comparison). The symbolic stage is the process of understanding ideas, abstractions, and concepts through language (Bruner 1966b, 21) 


\section{The role of computer graphics technology}

Graphic design is the activity of ideas packaging through design elements then make them published. Referring to Ellen Lupton,anyone who is able to access the design tools can turn ideas and concepts into graphic designs (Lupton 2006, 15). This is due to the easinessinaccessingtheinformation technology and graphic design technology. The development of computer graphics technology allows the manipulation of text and images through increasingly sophisticated automation capabilities. Computer technology forces graphic designers to change their work habits. Even the existence of industry will turn the world upside down through its power, so that a study of the tastes and stylesof design in the influence of the latest technology is needed. (Meggs 1983, viii). The shift in stylesoccurred was also influenced by technical obstacles and technological prices that were increasingly resolvedso that more and more people were able to use computer graphics. But the most fundamental thing from creative solutions is the ability to produce different ideas. If computer graphics allows designers to produce more creative ideas, it can be traced how computer graphic technology supported by the internet provides facilities for designers (Guilford 1987, 33).

The role of computer technology and the internet in design needs to be watched out, given the possibility that there is little evidence that this technology can improve the quality of design (Lawson 2004, 64). This statement is understandable given the fairly limited role of the internet in the early 2000s. But Lawson recognizes that computers are actually capable of playing several different roles in the design process. Computers can also strengthen the human mind to store, remember, and process information, and even manipulate images faster at affordable prices today.

Further,Lawson mentioned the important role of computers in designing because it is able to do work with accuracy and speed that far exceeds the ability of humans in general. Computers are also supported by artificial intelligence that is growing increasingly. The computer has the ability like a draftsman (Lawson 2002, 65-83). Thus this technology might not influence the design process much but rather play a role in supporting the design presentation. The basic thing that needs to be learned is the interaction of the designer with computer technology, bearing in mind the results of the design depend on the designer's role in integrating technology with his or her abilities. It is realized that Lawson's computer graphics technology has drawbacks such as reducing the taste and expression of the designer due to hardware work constraints such as mouseand pen tablets that are not as responsive as pens or pencils. But the lack of this technology does not rule out the possibility of study onthe experience of designer interacting with computer devices.

The connectionbetween designers and computer graphics technology is assumed to be a process that is full of experience in the crowdsourcing graphic designer phenomenon. Given the ability of computer graphics that are able to manipulate images easily. But all the sophistication provided by this technology will still depend on the ability of each designer. In this phase of interaction between designer and technology, knowledge can be obtained.

\section{Designer and user relationship}

Graphic design work generally starts with users who need help to solve design problems. The user's expectations are outlined in detail in the form of a briefing before the work begins, although there is a possibility of change at the time the work is done. Possible changes occur because of differences in the ability of each user in making briefings. Sometimes there are users who are able to make very specific briefings that make it easy for designers to do the work. But there are also users who only give general information in the brief (Mozota 2003, 194).

The problem of the relationship between designer and user can arise because ofa less specific briefing which results in a misinterpretation by the designer. This condition can be seen as a failure of the designer to understand user expectations. Likewise the user fails to inform the design goals. In such situations, the designer can communicate to understand the users and problems faced in a deeper and anticipate changes that might occur. The user usually acts as the initiator and the party who finances the design work, therefore it is very influential on the design decision(Pedgley 2009, 1-5). In the design process, demands, suggestions, and information from clients are usually not all presented in the form of a briefing at the beginning of the work but some appear gradually. Thus the communication process between the designer and the user during the design can be considered as meaningful and reflective communication. The communication that takes place is not only about understanding the user's expectations but also about understanding the user's character.

Reflective practice between the designer and the user is a creative act that is loaded with improvisation in the execution of work. The designer'sability to do reflective practice generally increases over time. This reflective practice by the designer is done bycommunicating with users and accommodating their expectations (Schön 1983, 295). Reflective practice initiated by Donald Schön actually originated from John Dewey who wrote reflective thinking that involves sequential and complementary ideas and determines actions or decisions (Dewey 1933, 16). 


\section{Design ethics}

The issue of design ethics needs to be explored, bearing in mind that from the very beginning, crowdsourcing graphic design has triggered polemic and rejection from professionals. Design ethics is a standard that regulates the behavior of designers and users which contains a set of agreed truth principles based on moral values. Graphic design ethics according to Eileen MacAvery Kane includes three aspects, namely legality, integrity, and morality (Kane 2010,6).Considering this research concerns the phenomenon of crowdsourcing that occurs on the internet, all aspects of ethics are referred,base on internationally accepted provisions.

a. The legal products regarding design ethics are basically clear enough to regulate right and wrong actions, but in scientific investigations based on field research there are always interesting cases to be analyzed. Aspects of the legality of the design include 1) Copyright that protects the intellectual property of the creator whose authenticity is stated through publication and claims. 2) License which regulates the use of design facilities such as software, images, photos, and fonts through legal purchases. 3) Plagiarism or copyingof all or part of other people's work and claim it as personal work(Kane 2010, 8-11).

b. Integrity is needed because graphic design is work that involves relationbetween actors (designers and users) that form an attitude of mutual trust. The issue of integrity includes honesty and authenticity that shapes the professionalism of the designer, adhering to the applicable agreement. The agreement includes 1) Employment agreement. As a framework for design work, AIGA issues the Standard Form of Agreement for Design Services. A standard agreement in a modular form that can be adapted to various needs of graphic design work. The standard purpose of the agreement is to protect the designer, user and all parties involved in a graphic design work. These standards cover the scope of work, time frame, and estimated costs. For this reason Kane explained the reason AIGA did not approve of speculative graphic design work such as crowdsourcing because the designer did the work for free in hopes of becoming a winner and getting a prize. Speculative graphic design work is considered asignoring the protection of the designer profession. The issue of design quality is being reviewed, considering that everyone can be involved in the graphic design crowdsourcing system. 2) Professional certification. Many countries including Indonesia have begun to apply certain professional standards with certification. Kane admitted that in the world of graphic design certification is still a matter of debate. Supporters of certification consider the need for certain capability standards to do graphic design work. While those who reject certification are of the opinion that graphic design does not belong to certain elites. The design work can be instinctively done by anyone (Kane 2010, 23-33).

c. Morality. Graphic design work is basically visual communication that has an effect on society. Graphic designers need to consider morality even though some designers consider the impact of communication on society to be the responsibility of the user (Kane 2010,37). Some moral aspects that need attention include. 1) Cultural impact. Graphic designers need to think about the impact of work on values in society. Graphic designs that contain sensitive elements need to be watched out so as not to cause social and cultural injury. 2) Consumtivism. The increasingly wasteful behavior of the community in purchasing consumer goods needs to be known by the designer as the impact of graphic designdevelopment. 3) Designer's social responsibility can be identified through their attention to the design work that carries social themes(Kane 2010, 38-44).

\section{Graphic design crowdsourcing disruption}

Changes in business direction have occurred since the mid 90s. Some large companies began to feel the effects of change with the emergence of new competitors who applied disruptive innovations (disruption) to the establishment of the business. The originator of the term disruption was Clayton M. Christensen, professor at Harvard Business School. Christensen outlines the disruption theory with the example of several large companies that went backwards, even falling because they could not compete with smaller companies that implemented new innovations (Christensen 1997, 7-9). Christensen's theory of disruption actually refers to Joseph Schumpeter's thought that the "storm of creative destruction" occurs in industries that are constantly revolutionizing economic structures through the destruction of old ones by the emergence of new ideas (Schumpeter 1943, 82-84). In the era of technological disruption, a well-managed company has failed, because management practices that make the company a leader in the industrial world actually make it very difficult to develop disruptive technology that can steal the market (Christensen 1997, 175-179).

Referring to disruption theory, the phenomenon of crowdsourcing graphic design is a significant disturbance to the existence of an established industry so far. Graphic design crowdsourcing is able to provide asystem that are accommodative to theshifting user behavior in graphic design. This is in line with Jeff Howe's idea that crowdsourcing has an inevitable development background through the rise of amateurs, the emergence of free software, the ease of obtaining production tools, and the emergence of communities that are bound by mutualinterest (Howe 2009, 2-8). Some of these form the phenomenon that occur today which are characterized by the utilization of collective intelligencepotential, mass production of creative work, the availability of unlimited digital storage space, the use of crowd resources at a relatively low cost. Crowdsourcing is able to 
change the way things work by providing abundant resources so that appropriate development models need to be prepared in the future.

\section{Public space in the internet era}

The existence of a graphic design crowdsourcing system is closely related to the public space concept on the internet. The idea of public space is actually not new. According toHabermas $(1989,27)$ the public space concept has existed since the 18th century in Europe, which was originally a space formed by the upper middle class responding to the power of public authority. The emergence of public space concept because in Europe at that time there was a cultural shift through easy access to more critical literature and journalism. Easy information access forms a new power that is concentrated in the public sphere.

Apart from criticism of the role of the upper middle class towards the concept of public space, Habermas conceptualizes institutional criteria in public space (Habermas 1989, 36). These criteria include.

a. Disregard of status so that the public has the same opportunity to the access of public space. The public is automatically equal in social matters or equal in the term ofauthority, but at least it has equal access to reveal and criticize a fact.

b. The issue of domains becomecommon concern (domain of common concern), considering that at that time, art issues for example were no longer regulated by state or church authorities, but had become a public problem. Artwork has become a commodity and is discussed among the people.

c. Inclusiveness characterizes a group of people. This is marked by the waning exclusivity of a group. No matter how exclusive a group is, the matters discussed in the public sphere will be everyone's concern.

The emergence of crowdsourcing graphic designer community in the internet era is still relevant when viewed from this institutional framework with adjustments influenced by increasingly interactive technological developments. Habermas's view of the internet is indeed limited to the early development of this technology, with the emergence of chat room which is still very simple. While the internet has now developed into a means of buying and selling goods and services that can be accessed by anyone. Still, Habermas's view of seeing the internet from the political dimension of media deserves to be a foothold in seeing this crowdsourcing phenomenon. Habermas $(2006,423)$ believes that the internet clearlyreactivates the grassroots through the egalitarian nature of internet media. This media reduces power which tends to suppress public opinion.

\section{Conclusion: Seeing other 's practices}

Various theories in the field of graphic design are an established rationale and are used in education and industry so far. To understandthe experience of the designer community requires an open view of the phenomenon. The consequence is that all findings that are contrary to established graphic design theory must be treated as new ideas that can be discussed and developed. For this reason, Emmanuel Levinas's rationale that is opened to the practice of others is used forapproachingof the graphic designer communityphenomenon.

Levinas studied phenomenology from Husserl but in a different way of looking at the phenomenon of consciousness. For Husserl, human consciousness is the benchmark for everything. Thus, the representation of a phenomenon must be digested by reason. The absoluteness of human consciousness in Husserl's transcendental idealism brought Levinas to the conclusion that in such a philosophy, human consciousness would subdue everything else (Tjaya 2015, 39-40). It is feared that such awareness will be trapped back into Descartes' concept of ego as the center of everything (Levinas 1998, 127).

Levinas' thinking boils down to ethics that involves one's relationships with others. For (Levinas 1979, 4243) encounters with other people should not aim to neutralize, dominate, even consider others as threats. The enlightenment project which considers other people's practices as deviations that need to be addressed, is opposed through Levinas thinking. The human itselfthat needs to open up to be questioned by others. This also applies to all theories that are already established and crystallize into dogma.

It is realized that Levinas's writings are not describing detailed methodological steps, but his main ideas about seeing the practices of others can be operationalized in this research. The attitude of the industry, associations, and graphic design professionals who look down on the practice of crowdsourcing designers is a condition that is just as disturbing as what Levinas imagined about the cruelty perpetrated by the invaders based on the attitude of looking down on humans, ethnicities, and even other nations. The way to see the practices of others by Levinas ischosen because it canbe the starting point for the development of various graphic design concepts in the future, by shifting the ego and the power of the mindof modern designers as the center of all ideas.

\section{References}

Airey, David. 2010. "Spec Work: Bad for Client, Bad for Designer.” 2010. https://www.davidairey.com/specwork-in-graphic-design.

Ambrose, Gavin, and Paul Harris. 2011. Design Thinking. Lausanne-Switzerland: AVA Publishing SA. 
Andriansyah, Miftah, Teddy Oswari, and Budi Prijanto. 2007. "Crowdsourcing: Konsep Sumber Daya Kerumunan Dalam Abad Partisipasi Komunitas Internet." Universitas Gunadarma, 1-6.

Barthes, Roland. 1972. Mythologies. New York: Noondy Press.

Bisnis.com. 2013. "SITUS 99DESIGN: 17.000 Desainer Indonesia Ikuti Kontes." 2013. http://entrepreneur.bisnis.com/read/20130608/263/143472/javascript.

Boden, Margaret A. 2004. The Creative Mind: Myths and Mechanisms. London: Routledge.

Bonnardel, Nathalie, and Franck Zenasni. 2010. "The Impact of Technology on Creativity in Design: An Enhancement?" Creativity and Innovation Management 19 (2): 180-91.

Brabham, Daren C. 2013. Crowdsourcing. Cambridge: The MIT Press.

Bruner, Jerome. 1966a. On Knowing: Essays for the Left Hand. New York: Atheneum. 1966b. Toward a Theory of Instruction. Cambridge: The Belknap Press of Harvard University Press.

Dewey, John. 1933. How We Think: A Restatement of the Relation of Reflective Thinking to the Educative Process. Boston: Houghton Mifflin.

Femia, Joseph V. 2006. Pareto and Political Theory. Oxford: Routledge.

Guilford, J.P. 1987. "Creative Research: Past, Present, and Future." In Frontiers of Creativity Research, edited by S.G. Isaksen, 33-65.

Habermas, Jürgen. 1989. The Structural Transformation of the Public Sphere: An Inquiry into a Category of Bourgeois Society. Cambridge: MIT Press.

2. 2006. "Political Communication in Media Society: Does Democracy Still Enjoy an Epistemic Dimension? The Impact of Normative Theory on Empirical Research." Communication Theory 16 (4): 411-26.

Hammon, Larissa, and Hajo Hippner. 2012. "Crowdsourcing." WIRTSCHAFTSINFORMATIK 3: 165-68.

Howe, Jeff. 2006. "The Rise of Crowdsourcing." Wired 14 (6). . 2009. Crowdsourcing: How the Power of the Crowd Is Driving the Future of Business. New York: Random House Business.

Kane, Eileen MacAvery. 2010. Ethics: A Graphic Designer's Field Guide. New York: Campbell Hall.

Lawson, Bryan. 2002. "CAD and Creativity: Does the Computer Really Help?” LEONARDO 35 (3): 327-331. 2004. What Designers Know. Oxford: Architectural Press.

Levinas, Emmanuel. 1979. Totality and Infinity: An Essay on Exteriority. Edited by Alphonso Lingis. Pittsburgh: Martinus Nijhoff Publishers \& Duquesne University Press.

. 1998. Discovering Existence with Husserl. Edited by Richard A. Cohen and Michael B. Smith. Illinois: Northwestern University Press.

Lupton, Ellen. 2006. D.I.Y. Design It Yourself. New York: Princeton Architectural Press.

Massanari, Adrienne. 2012. "DIY Design: How Crowdsourcing Sites Are Challenging Traditional Graphic Design Practice." First Monday 17 (10).

Medina, John. 2008. Brain Rules. Seattle WA: Pear Press.

Meggs, Phillip B. 1983. A History of Graphic Design. New York: Van Nostrand Reinhold.

Mozota, Brigitte B. de. 2003. Design Management: Using Design to Build Brand Value and Corporate Innovation. New York: Allworth Press.

Murtono, Taufik, and Didit W. Soewardikoen. 2017. "The Existence of Crowdsourcing Graphic Designers in Indonesia." In 4th Bandung Creative Movement International Conference on Creative Industries, $187-93$.

"NO!SPEC Design Organitations.” 2011. 2011. https://www.nospec.com/design-organisations.

Pedgley, Owain. 2009. "Influence of Stakeholders on Industrial Design Materials and Manufacturing Selection." International Journal of Design 3 (1): 1-15.

Pfiffner, Pamela. 2009. "Spec Work and Crowdsourcing: Gambles That Don't Pay Off." 2009. https://creativepro.com/spec-work-and-crowdsourcing-gambles-dont-pay.

Poon, Stephen. 2015. "Modernisation of Graphic Design: The Possibilities and Challenges of Digitalisation." Journal of Graphic Engineering and Design 6 (1): 5-9.

Provost, Lloyd P., and Gerald J. Langley. 1998. "The Importance of Concepts in Creativity and Improvement." Quality Progress 3 (1): 31-38.

Rina, Ratna Cahaya. 2016. "Kaliabu Dan Salaman, Ketika Internet Telah Menjamahmu: Cerita Tentang Desainer Kampung Di Indonesia.” PORTAL Journal of Multidisciplinary International Studies 13 (2): 1-5.

Rohidi, Tjetjep R. 2011. Metode Penelitian Seni. Semarang: Cipta Prima Nusantara.

Sammons, John, and Lars Daniel. 2017. Digital Forensics Trial Graphics: Teaching the Jury Though Effective Use of Visuals. London-San Diego-Cambridge-Oxford: Academic Press.

Schön, Donald A. 1983. The Reflective Practitioner. New York: Basic Books.

Schumpeter, Joseph. 1943. Capitalism, Socialism and Democracy. London-New York: Roudledge.

Shao, Bingjia, Lei Shi, Bo Xu, and Li Liu. 2012. "Factors Affecting Participation of Solvers in Crowdsourcing: An Empirical Study from China.” Electronic Markets The International Journal on Networked Business 22 
(2): 73-82.

Ståhlbröst, Anna, Constantinos Marios Angelopoulos, Orestis Evangelatos, Srdjan Krco, Sotiris Nikoletseas, Theofanis Raptis, and Sebastien Ziegler. 2015. "Understanding Modes of Crowdsourcing and Related Crowd Motivators." In The XXVI ISPIM Conference- Shaping the Frontiers of Innovation Management, 117. Budapest-Hungary.

Tjaya, Thomas Hidya. 2015. Enigma Wajah Orang Lain: Menggali Pemikiran Emmanuel Levinas. Jakarta: Kepustakaan Populer Gramedia.

Triggs, Teal. 2009. "Designing Graphic Design History.” Journal of Design History 22 (4): 325-40.

Wee, Willis. 2013. "There's Raw Talent in Indonesia and Philippines." 2013. https://www.techinasia.com/99designs-raw-talent-indonesia-philippines.

Weinschenk, Susan. 2012. 100 Things Every Designer Needs to Know About People. Berkeley CA: New Reader. William, Robin. 2004. Non-Designer's Design Book. Berkeley CA: Peachpit Press.

Young, James Webb. 2003. A Technique for Producing Ideas. McGraw-Hill Education.

Yulfa, Arie. 2012. "Crowdsourcing Sebagai Upaya Melibatkan Peran Masyarakat Dalam Proses Perencanaan Wilayah.” Jurnal Skala 2 (4): 13-23.

Zhao, Yuxiang, and Qinghua Zhu. 2012. "Exploring the Motivation of Participants in Crowdsourcing Contest." In 33th International Conference on Information Systems, 1-13. Orlando. 